\title{
Oscillating between Madness and Badness: The Untenable Situation in A Streetcar Named Desire
}

\author{
Samira Sasani \\ Assistant Prof. of English Literature, Shiraz University \\ ssasani@shirazu.ac.ir
}

\section{Doi:10.5901/mjss.2015.v6n1s1p481}

\begin{abstract}
Tennessee Williams's A Streetcar Named Desire depicts a pathological interaction among the characters, which is the subject matter of anti-psychiatrists such as Watzlawick and Laing whose theories are applied to the William's play. Reading the play, one may ask himself how come that two people who are quite nice when considered on their own can be such devils when put in each other's company? In these game-like interactions, Blanche is unknowingly entrapped in an untenable position from which her chance of stepping outside is very slim; it is called untenable since a person entrapped in it should choose between madness and badness. Once, in her past life, she chose to be bad and now in Stanley's hands she has no other choice than being mad. The game is over when Blanche is made mad and is institutionalized by Stanley and his team members, Stella and Mitch.
\end{abstract}

Keywords: A Streetcar Named Desire, pathological interaction, untenable situation, Watzlawick, Laing

It is not the things themselves which trouble us, but the opinions which we have about these things.

Epictetus (quoted in Watzlawick 1967, p.257)

\section{Introduction}

Modern drama is replete with different forms of entrapment in relationships. Pinter's plays, such as Caretaker, Betrayal and The Birthday Party; Eugene O'Neill's Long Day's Journey into Night, and Recklessness; Lars Noren's Silence, to name a few, are all portraying different forms of entrapment in pathological relationships and investigating these forms of pathological interactions is at the center of attention of anti-psychiatrists. Like many of modern family plays, A Streetcar Named Desire portrays a small family composing of few characters; though four main characters run forward the plot of the play: a husband and a wife, Stanley and Stella; their guest, Stella's sister (Blanche); and Stanley's friend, Mitch.

All these characters try to understand one another and to establish a good relationship, but they are not that much successful. Communicating well without being trapped in the relationships happens rarely in modern drama. The characters in these plays are entrapped in the untenable situations from with there is no vent out. These characters start playing with one another and the wiser ones who are in one-up position win the game; though the weaker ones, or the ones who are less wise oscillates between madness and badness, the untenable situation, and the more they try to set themselves free the more the noose tightens.

Stella, Stanley, Mitch and Blanche are really nice when they are considered on their own but when they want to communicate and make relationships they are entrapped in a chess-like game. However, Stanley and Blanche, the more active and prominent characters by whom the play mainly goes forward, are more entrapped and the more the weaker characters try to alleviate the crisis, the more the condition degenerates. Among these four main characters, Blanche has been more disturbed mentally and is made mad. The definition of madness proposed by anti-psychiatrists is completely different from what proposed by psychiatrists. Blanche, as she frequently points to, is a character trapped in the pathological interactions and she has no other choice than choosing badness or madness.

\section{Watzlawick and Laing's Communication Theory}

Anti-psychiatrists such as Watlawick and Laing work on the pathological interactions. Watzlawick's Pragmatics of Human Communication: A Study of Interactional Patterns, Pathologies, and Paradoxes is the study of pragmatic effects of human communication, in which disturbed behavior is seen as a communicative reaction to a particular situation rather than the evidence of the disease of an individual mind. Gregory Bateson defines communication as "the study of the reactions of 
individuals to the reactions of other individuals" while we should observe "not only A's reactions to B's behavior, but we must go on to consider how these affect B's later behavior and the effect of this on A" (qtd in Watzlawick 1967, p.153).

Based on Watzlawick's communication theory the following patterns of interaction are distinguishable among people: symmetrical, complementary and metacomplementary, which can be described as relationships based on either equality or difference. Symmetrical interaction is characterized by equality and the minimization of difference, while complementary interaction is based on the maximization of difference. In the third case, which is also called "pseudosymmetry", A lets or forces B to be in charge of him. In other words, A lets or forces B to be symmetrical. In A Streetcar Named Desire, the second type of pathological communication, complementary, is conceivable. The pathologies of complementary relationships tend to amount to disconfirmation rather than rejections of the other's self (Watzlawick 1967, p.108). In this kind of interaction, one partner may occupy the position of the superior, primary or "oneup" position, and consequently the other occupies the inferior, the secondary or "one-down" position (Watzlawick 1967, p.69). In this kind of interaction, $A$ is culturally labeled as an assertive and $B$ is considered as a submissive character.

In Laing's view, in complementary relationships, "collusion" is at the center and we observe a growing sense of frustration and despair in one or both partners. Delusion, as Laing says, implies total self-deception; illusion implies a capacity to deceive oneself under a strong wish, but does not involve as total as self-deception as delusion. So collusion is a "game" played by two or more people whereby they deceive themselves. It is a game involving mutual self-deception. So collusion is necessarily a trans-personal or interpersonal process $(1960, p .98)$. Complaints of increasingly frightening feelings of self-estrangement and depersonalization are very frequently voiced by the individuals entrapped in collusion. They are perfectly capable of functioning satisfactorily when they are considered on their own but this picture often changes dramatically when these individuals are put in each other's company and when they are seen together with their "complements" (Watzlawick 1967, p.109). Thus the "folie a deux" or the "folie a plusieurs"-a group departure from reality-is the most remarkable pathology happens in these complementary relationships.

In this pathological relationship, the weaker character is entrapped in a double-bind or paradoxical injunction. A person caught in paradoxical injunction or double bind is in untenable position from which his chance of stepping outside is very slim. Watzlawick suggests different examples to clarify this situation which ultimately leads to the untenable situation no one wants to be engulfed in. This situation is called untenable, since a person entrapped in it should choose between "badness" and "madness" (1967, p.212). According to Laing, one person's position may be rendered untenable by others. He argues that the initiation of any kind of interpersonal reaction tending to foster confusion can drive the other crazy; in this case it is difficult for a person to know 'who he is' and 'who the other is'. Thus, concerning Blanche's situation, Corrigan argues that "being forced to face the kind of reality that she refuses to recognize as significant is the cause of Blanche's breakdown" (2006, p.219).

As Laing says, in these double-bind situations two or more persons are involved, of whom one is regarded as the 'victim'. The victim is thus in an untenable position and cannot make a single move without evoking a catastrophe. So what we can observe in virtually all these cases of pathological communication is that they are vicious circles and cannot be broken unless the communicants step outside the circle, which is not possible except by a "violent change" such as suicide, and homicide as Watzlawick suggests (1967, p.235).

\section{Analysis of a Streetcar Named Desire}

Blanche's life is divided into two periods, in one part of her life, Blanche chooses to be bad and in the other part, she chooses to be mad. Actually, being entrapped in the relationships, she has no other choice than being bad or mad. Departure from reality is the cause of her consequent problems, though Clum believes that "A Streetcar Named Desire suggests that those who aren't strait must act in order to survive and that they must imaginatively transform a world in which they are rejected into a bearable place" (2006, p.275).But, indeed, folie a plusieurs, or group departure from reality is almost the cause of all the pathological interactions which happen in modern plays. In one part of the play, she accepts that she is a person who does not like reality. She surely lives in her dreams and desires, or as O'Neill calls it, in her "pipe-dreams". Thus, the more she tries to set herself free, the more she is entwined in the web. Ruby Cohn believes that Blanch "is trapped by the poverty of her imagery which reflects the poverty of her dreams, like Miller's Willie Loman" (1977, p.49).

Blanche is the defeated person, the loser in a game with Stanley. Both she and Stanley try to control the game and both think that they are the manipulators, but Stanley is wiser and wins the game. Having been several times defeated by different people she was living with and communicating with in her past life, now, Blanche resorts to fantasies more and gets further and further from reality, which is the cause of her later failures. The way she lives in reality is very much like touching objects in darkness; thus her understanding of her position and situation is limited and she mostly miscalculates. 
Therefore, her failure is not because of her madness but because of the situation she is engulfed in, the darkness, and the world of fantasies she is entrapped in. Thus, the more she struggles, the more she plunges into the ocean of failures, and the more dragged down into the quicksand of deceits and frauds. Bigsby stipulates that William's characters "frequently tread the boundary of insanity, driven towards this territory partly by the callousness of others and partly by their own preference for the fictive, the imaginary, the unreal." (1992, p.44)

The whole play is replete with different games such as bowling, and poker which symbolize the prominent game of deceits and frauds against Blanche. The fixed partner of all these games is Stanley who is very dexterously manipulating the games. Though he is defeated sometimes and gets wildly angry, he is the final winner of the game set between himself and Blanch. It is Stanley who sets the game, controls it and generally speaking abuses Blanche who is far from reality. Blanche also plays her deceitful game but she is not successful since she is not living in reality, which is her weak point, and cannot assess the happenings well. Before Blanche's arrival, Stanley symbolically plays bowling which does not need any partner, he can play it alone and hits the pins which would be the symbol of his relationship with his wife, Stella. But after Blanche's arrival, he symbolically plays poker indicating the way he plays with Blanche; the way he trapped her in the game of deception and the way he keeps some cards hidden. As Cohn says: "Williams had intended at first to call his play The Poker Game, and the actual title may indicate his shift of focus from Stanley to Blanche" (1977, p.51).

The way the play proceeds and ends in Blanche's defeat and madness is very similar to the setting of the paly which starts in Spring and ends in Fall. Blanche reaches at Elysian Fields while she is perplexedly searching the address in her hands. Very symbolically Eunice, Stella's neighbor, asks her: "What's the matter, honey, Are you lost?" (Williams 1947, p.6). She is really lost in the world of reality and as she herself unknowingly responses, she is actually trapped in the game in which she is deadly buried. She is coming to her grave by her fantasies, her desires, her detachment from reality or as she unknowingly refers to by a streetcar named desire.

From the very first moments of her arrival, having been defeated in the other games of life, Blanche theoretically tries not to get involved in any relationship. She asks Eunice to leave her alone. She faintly murmurs to herself: "I've got to keep hold of myself" (Williams 1947, p.10), though paradoxically, she practically establishes relationships, however pathological. She says something but does another thing. Before coming to Stella's house she had experienced the pathological relationships in which she decided to be bad rather than mad. Jackson argues that like Orestes "she has made a guilty choice: a choice which has involved her in the suffering of others" (1966, p.81). Now, coming to Stella's house is a turning point in her life and she does not want to repeat those pathological interactions. Coming to Stella's house is a turning point in her life but it does not mean that she has come out of the entrapment. The game she has been engulfed in is actually a game without end and Stella tries to come out of it by forgetting it, even by concealing it, though her past is her present and the present is her future and this strategy, concealment, does not work well since it is another form of being bad exposed in a form of hypocrisy.

Blanche is not realistic and her departure from reality is her problem which she is totally unaware and even she is boasting about it. She repeats her mistakes and remains in the pathological game, in the untenable situation which leads indispensably to badness or madness. Blanche disguises the story of dismissing from the high school to cover up her badness; though in spite of all her deceptions and hypocrisies, she calls Stella a liar, several times throughout the play. She accuses Stella of leaving Belle Reve and leaving all the burden of life on her shoulders. Whatever Blanche is accusing others of committing is truly a cover on her corrupt past, of what she is actually accused of. Blanche lost Belle Reve and she blames Stella for it.

Blanche is very much worried about how other people receive her. She asks about Stanley and his attitudes; she wonders whether Stanley will like her or she will be just a visiting in-law for him. She admonishes Stella that she cannot stand it if he does not receive her warmly. Stella, on the other hand, ensures her that they will "get along fine together"(Williams 1947, p.17), which would sound ironic to Blanche since she is plotting something else. When Stanley sees Blanche, he asks her about her occupation and also her past marriage. Referring to her past marriage makes Blanche sick, because these questions proposed by Stanley would uncover her shameful past, which she tries to conceal. She does not dare encounter reality and this leads her to the subsequent failures in the same game which starts from her past life. Although this time her deceitful partner is Stanley and she is entrapped in an untenable situation in which she chooses madness rather than badness.

Blanche's arrival coincides with Stanley's poker night. Bowling symbolically changes to poker up to the very end of the play. The game starts when Stella makes Stanley aware of losing Belle Reve; actually she unknowingly informs him of her weak points. Stanley starts the game by mentioning the Napoleonic code according to which what belongs to the wife belongs to the husband and vice versa, thus the game against Blanche starts with this excuse. Blanche is the guest who disturbs Stanley's comfort, while "be comfortable" is his motto, as Stanley once told Blanche (Williams 1947, p.26). 
Stanley starts complaining to Stella that "it looks to me like you have been swindled, baby, and when you're swindled under the Napoleonic code I'm swindled too. And I don't like to be swindled." (Williams 1947, p.33).

Stanley employs the word "swindle"; it is as if they have been cheated and defeated in a game of deceits and frauds set by Blanche. Stella complains about what he said but she herself unknowingly makes Stanley aware of Blanche's weaknesses and tells him how easily she goes to pieces, which can be very good news for Stanley to hear of his opponent's weak points:

\author{
Stella: There's plenty of time to ask her questions later but if you do now she'll go to pieces again. I don't understand \\ what happened to Belle Reve but you don't know how ridiculous you are being when you suggest that my sister or I or \\ anyone of our family could have perpetrated a swindle on anyone else. \\ Stanley: Then where's the money if the place was sold? \\ Stella: Not sold-lost, lost! (Williams 1947, p.33) \\ Stella leaves the room but Stanley stays there to ask Blanche about Belle Reve. When Blanche comes out of the \\ bathroom she starts flirting with Stanley but she cannot engage him in her play. Blanche declares it to Stanley: "I cannot \\ imagine any witch of a woman casting a spell over you" and Stanley approves: "That's—right" (Williams 1947, p.39). \\ Stanley notifies her of Napoleonic code and asks her to tell him the truth and not to play with him. But Blanche makes \\ him sure that she does not deceive him and does not play with him: \\ Stanley: If I didn't know that you was my wife's sister I'd get ideas about you! \\ Blanche: Such as what! \\ Stanley: Don't play so dumb. You know what! \\ Blanche: . . . I know I fib a good deal. After all, a woman's charm is fifty percent illusion, but when a thing is important I \\ tell the truth, and this is the truth: I haven't cheated my sister or you or anyone else as long as I have lived. (Williams \\ 1947, p.41)
}

Blanche asks Stanley: ". . . What's in the back of that little boy's mind of yours? That I am absconding with something attempting some kind of treachery on my sister?" (Williams 1947 p.42). Blanche is very much hurt by Stanley's incivility when he aggressively probes her trunk which is full of love letters her ex-husband had written to her. Once, in the past, she played against her husband and now the same story happens and Stanley is playing with her. She acknowledges to Stanley: "I hurt him the way you would like to hurt me, but you can't! I'm not young and vulnerable any more. But my young husband was and I-" (Williams 1947, pp.42-3). Now, Blanche understands that she is in a game and her opponent is Stanley. He has started the game and she understands it but what she is unaware of is that she is not the manipulator of the game and in spite of what she says about herself, she is very much vulnerable to his hoaxes.

Blanche steps in a pathological interaction with Stanley and she thinks that she can control the game with duplicity and deception, or generally with detachment from reality which, according to anti-psychiatrists' theories, leads to untenable situation. But Blanche is totally ignorant of her basic problem, the world of fancies she is living in. She thinks that her corrupt past is the cause of her problems in her sister's house, thus she tries to conceal it with deception. Bigsby suggests, Williams "acknowledges the impossibility of recovering the past" (1992, p.33). However Bigsby suggests that "Stanley has no past. He comes into existence ready-made and fully known" (1992, p.50). But Blanche is quite other.

This vicious circle, she is engulfed in, does not stop till she inevitably chooses again between badness and madness. She cannot assess the situation she is living in well, consequently she cannot assess Stanley and the game he plays against her well. Blanche very easily entrapped in his trap and gets mad as he has planned. Stanley, so nicely, carries out his plan that Blanche does not understand it till the very end of the play when she is forcefully taken to the asylum. She even enjoys the game in which she thinks that she is the manipulator; she thinks that it is she who is deceiving Stanley by covering up her shameful past.

Blanche thinks that if she does not see the reality as it is, and if she resorts to the world of illusions, it would change her past and consequently her present but she is unaware of the fact that it has been exactly the opposite and it has been the cause of her failures. While Stanley is playing poker, which symbolizes the game she plays with Blanche, she gets very much fascinated with the game and suggests Stanley if she could be a kibitz. She is totally unaware that it is Stanley who is a kibitz in a game played between them. Each time Stanley intentionally talks to her about her past, and about Belle Reve, Blanche feels sick and her nerves are in knots, as she explains, so she goes to the bathroom and takes a shower. It appeases her nerves and makes her somehow ready to receive other strikes from Stanley, her opponent. "Like her drinking, her bathing is an escape mechanism", Corrigan declares (2006, p.217).

Blanche starts belittling Stanley in the eyes of his wife, Stella, but Stella is very much in love with him and believes that shortcomings and severity of life is necessarily parts and parcels of reality, thus she does not entrapped in Blanche's game against Stanley. Stella wisely does not accept to become Blanche's accomplice and does not make an ally against Stanley. Blanche undermines Stanley but Stella warns her of his ambition and capabilities, which truly frightens Blanche: 
Blanche: I'm sorry, but I haven't noticed the stamp of genius even on Stanley's forehead.

[.... The game has continued in undertones.]

Stella: It isn't on his forehead and it isn't genius.

Blanche: Oh, well, what is it, and where? I would like to know.

Stella: It's a drive that he has. You're standing in the light, Blanche. (Williams 1947, p.53)

Blanche belittles Stanley to cover up her own shortcomings. On the other hand, she is very much worried about her true identity and does not want to reveal it to anybody, thus she absconds from light; she even buys a little colored paper lantern at a Chinese shop and puts it over the light bulb to reduce the light of the house. Stella very ironically warns Blanche that she is standing in the light; in other words she ironically warns her that she understands the game Blanche is playing against Stanley. Besides, Stella warns Blanche that Blanche's opponent is powerful, very much like the way she informs Stanley of Blanche's traits, especially her weaknesses. Thus Stella plays the role of a mediator and introduces the opponents to each other. She actually plays in Stanley's team.

Another character who enters the game between Stanley and Blanche is Mitch. Mitch is Stanley's friend and is alone like Blanche. When Mitch sees Blanche in Stanley's house, he becomes interested in her. Mitch shows Blanche an inscription received from his dead girlfriend. They think that they are very much like each other and can marry but both of them are inevitably trapped in Stanley's game against Blanche. Stanley makes an ally with Mitch, and Mitch also cooperates with him as his friend. But, very much like Blanche who at the end of the play understands Stanley's plot, Mitch becomes aware of Stanley's game at the end of the play when Blanche is taken into the asylum. Everybody is controlled directly or indirectly by Stanley. Stella, Mitch, Blanch are like puppets in the hands of Stanley, though they are unaware of it. Stanley with the help of all these characters runs the game forward and defeats Blanche who is in onedown position compared to him.

Stella is beaten by Stanley several times. She cannot complain about poker he is playing in the house; she, however, considers it as part of life, a reality of life. She very soon forgives him and returns to her house. Several times, Blanche tries to make her aware of her sordid life but she is in love with Stanley and cannot leave him. However, what Blanche tells Stella about Stella's life is not out of Blanche's understanding and awareness but out of her disgust and deception against Stanley:

\section{Blanche: Pull yourself together and face the facts. \\ Stella: What are they, in your opinion? \\ Blanche: In my opinion? You're married to a madman! \\ Stella: No! \\ Blanche: Yes, you are, your fix is worse than mine is! Only you're not being sensible about it. I'm going to do something. Get hold of myself and make myself a new life! (Williams 1947, p.73)}

Blanche considers Stanley's action as "violence" (Williams 1947, p.68), as "lunacy, absolute lunacy!" (Williams 1947, p.63). Blanche wants to make a team against Stanley, though she knows it well that both Stanley and Stella love each other a lot. She thinks that she can defeat him strongly by braking up his marriage. Both Stella and Blanche are in the hands of Stanley, though in different forms. Stella vehemently loves Stanley and cannot see the reality of her sordid life; on the other hand, Blanche thinks unrealistically and lives in the world of fantasies and is not able to assess Stanley's plots well. Both Stella and Blanche are blind; Stella is blind towards Stanley but Blanche towards life in general. Once, Blanche ironically notifies it to Stella: "The blind are leading the blind!" (Williams 1947, p.45).

Blanche, who is unknowingly struggling in a web set by Stanley, admonishes Stella to get out of the entrapment. She advises her to come out of the game with Stanley, but she is totally unaware that the one who is plunging deep into the ocean of frauds is she, herself, not Stella. Stella loves Stanley and cannot leave him; Stella complains to Blanche: "You take it for granted that I am in something that I want to get out of" (Williams 1947, p.80), but Blanche believes that it is not love that makes her stay in the relationship but it is called desire: "What you are talking about is brutal desirejust—Desire!" (Williams 1947, p.81).

Stanley overhears Stella and Blanche's conversation in which Blanche calls Stanley an animal. Blanche starts backbiting against Stanley, her opponent who is now listening to her sayings. Blanche says: "well-if you'll forgive mehe's common!" (Williams 1947, p.82), "he acts like an animal, has an animal habits!" (Williams 1947, p.83). Blanche is playing her role in her game with Stanley quite openly, while her opponent who is the wiser character, who is in one-up position, plays very dexterously and his deceptions are opaque. "In pitting Blanche and Stanley against one another, Williams returns to his oft-told tale of the defeat of the weak by the strong" (Corrigan 2006, p.222). Comparing their interaction to card playing, to poker, Blanche has openly showed all her cards while Stanley is a kibitz and has hidden 
some of his cards. Heintzelman states that Blanche's "critical opinion of the dismal apartment and of Stanley's brutish demeanor creates a chasm in the sisters' relationship, and her chances of familial bonding are sacrificed" (2005, p.275). Yes, it is Blanche who unwisely sacrifices not only her familial bonding, but her whole life in the power game set by Stanley.

Stanley comes to the room, he ostensibly ignores what he has heard, but this happening makes him wiser and more invincible. Now it is the time of displaying one of his cards; it is the time of striking Blanche's nerves. He mentions the name of "Shaw" and "Hotel Flamingo" (Williams 1947, p.89) to her just to remind her of her corrupt past. Trembling, Blanche resorts to her sister and reveals to her the truth of her past; she asks Stella whether she has heard anything about her or not. Blanche cannot rely on Stanley's sayings. She is not sure whether she is deluded or not. She confesses to Stella: "I wasn't so good the last two years or so, after Belle Reve had started to slip through my fingers" (Williams 1947, p.91), "and I-I'm fading now! I don't know how much longer I can turn the trick" (Williams 1947, p.92). Blanche getting confused and befuddled confesses to her sister but Stella reacts in a way as if she has not heard anything. As she is not successful in engaging Stella in her plot, Blanche behaves madly, she screams without knowing its reason. She is truly affected by Stanley's stroke.

Blanche who cannot make a team with Stella decides to make a team with Mitch. Being defeated by Stella who does not participate in Blanche's plot against Stanley, Blanche gets befuddled; she needs a partner to defeat Stanley. Mitch is kind to her and it is what she needs at this moment:

Mitch: I showed you the inscription, didn't I?

Blanche: Yes. [During the pause, she looks up at the sky] There's so much-so much confusion in the world ... [He coughs diffidently] Thank you for being so kind! I need kindness now. (Williams 1947, p.69)

Blanche tries to entrap Mitch in her game and to make a team with him against Stanley. "I want to deceive him enough to make him—want me", she tells Stella (Williams 1947, p.95). Telling Mitch about her deplorable condition, she stirs Mick's emotions to deceive him: "you know as well as I do that a single girl, a girl alone in the world, has got to keep a firm hold on her emotions or she'll be lost!" (Williams 1947, p.103). She also tells Mitch about her miserable condition in Stanley's house. She tells Mitch "the first time I laid eyes on him I thought to myself, that man is my executioner! That man will destroy me" (Williams 1947, p.111).

Blanche: . . . If it weren't for Stella about to have a baby, I wouldn't be able to endure things here.

Mitch: He isn't-nice to you?

Blanche: He is insufferably rude. Goes out of his way to offend me! (Williams 1947, p.110)

Mitch very simply entrapped in her game and proposes marriage to her. Blanche thinks that she has been successful in controlling the game and she will be the winner. After his proposal, she happily cries out: "sometimesthere's God—so quickly!" (Williams 1947, p.116).

In spite of Blanche's quick and explicit tricks, Stanley very wisely and slowly is running the game forward and still has some cards hidden. Stella asks Stanley to stop picking on Blanche but Stanley cannot forgive Blanche: "that girl calls me common!" Stanley says (Williams 1947, p.118). Stanley follows up Blanche's affairs and gets proof of what he has suspected. Stanley is running the game to its end by striking Blanche once again, and eventually makes her mad. Stanley reports to Stella of the lies Blanche has told them. He warns Stella: "the cat's out of the bag! I found out something!" (Williams 1947, p.118). He tells her of Hotel Flamingo and Blanche's affairs there and also of her affairs with a seventeen-year-old boy and that she is practically told by the mayor to get out of the town, and is dismissed her post as a teacher. While he is reporting the news to Stella, Blanche who is, as usual, in the bathroom, ironically recites: "it's a Barnum and Bailey world, just as phony as it can be—but it wouldn't make believe if you believe in me!" (Williams 1947, p.120).

Stanley is working on the members of his team, on Stella and Mitch, though Blanche is unaware of it and thinks that it is she who manipulates the game of deceits. She is entrapped in the game of collusion which Stanley has set against her. Stella cannot believe it first and complains to Stanley why he has told Mitch all these stories about Blanche. Stanley convinces Stella: "Mitch is a buddy of mine. We were in the same outfit together-Two-forty-first Engineers. We work in the same plant and now on the same bowling team. You think I could face him if-" (Williams 1947, p.125). As Stanley has planned, Mitch does not come to Blanche's birthday party. Mitch is controlled by Stanley and they both are playing in the same team against Blanche. Stanley has made all his puppets-Stella and Mitch-against Blanche; the game of collusion against Blanche is reaching to its last minutes. Stanley addresses both Blanche and Stella, his puppets: "what do you two think you are? A pair of queens? Remember what Huey Long said-"Every Man is King!" And 
I am the king around here, so don't forget it!" (Williams 1947, p.131).

Blanche who has been happy of Mitch's proposal finds herself alone again without Mitch at the table. The story she narrates to Stella and Stanley at the table ironically refers to the uncovering of the truth, to facing with reality she is much afraid of. The preacher of her story symbolizes Blanche herself, while the parrot symbolizes Stanley who deceitfully uncovers the truth to retaliate Blanche who plays against him by telling lies and also to retaliate her for her explicit insults to him, for calling him "common". Stella accuses Stanley of entrapping Blanche in his game of deceits. Blanche has been a victim, indeed, in the hands of the people of the society who have played against her. Stella tells Stanley: "nobody, nobody, was tender and trusting as she was. But people like you abused her, and forced her to change." (Williams 1947, p.136) This change is a terrible change to madness rather than badness. Blanche has decided not to be bad anymore. Encountering a young man collecting for The Evening Star, Blanche reminds herself of the promise she had made not to be bad anymore, she tells the boy: "it would be nice to keep you, but I've got to be good-and keep my hands off children." (Williams 1947, p.99). Thus the only choice left in her untenable situation she is engulfed in by Stanley is madness.

After her birthday party held without Mitch, Blanche and Mitch see one another once again. Blanche complains to Mitch why he had forgotten his invitation but Mitch blindly repeats Stanley's sayings without knowing that he is manipulating by Stanley and that he is engulfed in Stanley's plot against Blanche. Blanche warns him "of course you don't really mean to be insulting!" while Mitch replies: "No, just realistic." (Williams 1947, p.144). Blanche is gradually secluded and is retreating to her loneliness; that is what Stanley has planned and now is getting closer and closer to his end. In her conversation with Mitch, Blanche unknowingly points to the cause of all her pathological interactions with others, her badness in the past and her madness now. Indeed, "every relationship for her is an adventure" (Kataria 2009, p.25). She tells Mitch: "I don't want realism. I want magic! [Mitch laughs] Yes, yes, magic! I try to give that to people. I misrepresent things to them. I don't tell truth, I tell what ought to be truth. And if that is sinful, then let me damned for it!-Don't turn the light on!" (145).

Blanche tries to convince Mitch that the merchant Kiefaber made up all these fake stories about Blanche to revenge her, but Mitch who is Stanley's accomplice and playing in his team does not sympathize with her or even protect her from Stanley's plot. Blanche resorts to the world of fantasies, to the pipe-dreams again. Finding herself in an untenable situation again, Blanche resorts to her dreams, to imaginary Mr. Shep Huntleigh, a rich man whom she desires to protect her. "Blanche's gradual emotional collapse is presented stage by stage" (Corrigan 2006, p.224). At this moment Blanche is completely drowned in her dreams and is furthest removed from reality, thus this is the appropriate time for Stanley to shoot his last bullets and show his last cards. Now, it is the time of revelation; he tells Blanche that he has known from the very beginning the rules of her deceitful game: "there isn't a goddam thing but imagination!", "and lies and conceit and tricks!" (Williams 1947, p.158). Koprince states that "Blanche is fragile and dependent, Stanley is powerful and controlling" (2008, p.34).What he tells Blanche extremely damages her. Stanley reveals to her that he has been playing with her and has been controlling the game; though she has been unaware and has wrongly considered herself as the manipulator:

I've been on to you from the start! Not once did you pull any wool over this boy's eyes! You come in here and sprinkle the place with powder and spray perfume and cover the light-bulb with a paper lantern, and lo and behold the place has turned into Egypt and you are the Queen of the Nile! Sitting on your throne and swilling down my liquor! (Williams 1947, p.158)

Blanche, who is extremely shocked, cries out: "in desperate, desperate circumstances! Help me! Caught in a trap. Caught in -" (Williams 1947, p.161). Stanley, the winner of the game, springs towards her, catches her wrist and shouts: "tiger-tiger! ... We've had this date with each other from the beginning!" (162) and he rapes her. "Stanley strips away Blanche's illusions and forces her to face animal reality", Corrigan states (2006, p.221)

After that physical and mental conquest over Blanche, now Stanley plans the last shot, to knock her out. Stanley has been successful to get Blanche to the point of madness. Now is the time of exploiting his plan, to finish his game by sending Blanche to the asylum. Stella who is playing in his team also helps her husband to defeat Blanche. Stella feels that she is guilty of what she has done to Blanche: "what have I done to my sister? Oh, God, what have I done to my sister?" (Williams 1947, p.176). Stella, who is not satisfied with what she has done, acquits herself by saying: "I couldn't believe her story and go on living with Stanley" (Williams 1947, p.165). Koprince asserts that "the rape allows him [Stanley] to destroy Blanche, who is subsequently sent to a mental asylum, but it also allows him to inflict tremendous psychological abuse on Stella", who "must live with her guilt about institutionalizing her sister" (2009, p.57). "The breach of trust between her and Stanley will likely not be healed, at least not fully", Hovis suggests (2007, p.184).

Everybody is helping Stanley and acquits himself of what he has done to Blanche. Eunice consoles Stella: "Don't ever believe it. Life has got to go on. No matter what happens, you've got to keep ongoing". Mitch who is still playing 
poker with Stanley seems worried and also sad about what he has done. As the stage direction reads towards the end of the play: "at the sound of Blanche's voice Mitch's arm supporting his cards sagged and his gaze is dissolved into space. Stanley slaps him on the shoulder" (Williams 1947, p.167); "Mitch keeps staring down at his hands on the table, but the other men look at her curiously" (Williams 1947, p.174). Mitch has been the puppet in the hands of Stanley and should do as Stanley wills, though it is against his desire.

Mitch, very much like Stella, knows that what he has done is wrong and knows that he has been one of the pawns of Stanley in his chess-like game. At the end of the play Mitch wants to go to the bedroom where Blanche is, but as the stage direction reads: "Stanley crosses to block him", as he does blocks his marriage with Blanche; "Stanley pushes him aside. Mitch lunges and strikes at Stanley", but it is too late; "Stanley pushes Mitch back. Mitch collapses at the table, sobbing" (Williams 1947, p.177). Blanche, the victim, the entrapped character, who understands now that she is in the untenable position, the double-bind, cries out: "I'm anxious to get out of here-this place is a trap!" (Williams 1947, p.169). Hirsch stipulates that "in A Streetcar Named Desire, Stanley Kowalski's seduction of Blanche Du Bois is not merely the victory of a hard-hat over a coy Southern belle, it is the representation of Williams's conviction that the meek shall not inherit the earth" (1979, p.4).

\section{Conclusion}

As soon as the Doctor rings the doorbell, the murmur of the poker game is interrupted very much like the murmur of the pathological game and the last words said by Blanche to the Doctor are: "whoever you are-I have always depended on the kindness of strangers" (Williams 1947, p.178). Whatever intimate relationship she establishes leads to a pathological interaction from which there is no vent out for her, thus the best people are strangers with whom she does not have intimate relationships and consequently she is not entrapped in pathological interactions with them. Her family interactions and also her intimate relationships with others, for instance, lead her to befuddlement and consequently to badness or madness. In these pathological games, she appears as a victim of the game. Far from reality, she cannot assess well the situations she is encountered with. So she is entrapped in the games of deceits and she has no other choice than being mad or bad. She chose to be bad when she was entrapped in the intimate relationships of her past life. Very much like what Stanley does to Blanche, uncovering her ex-husband's shameful deeds and affairs, Blanche made her ex-husband mad which leads to his committing suicide; thus, in her past life, very much like what Stanley has done to her, she chose to be bad rather than mad.

In her new life in Stanley's house, she is once again entrapped in a double bind situation. She should choose between badness and madness. But since she has terrible experience of being bad, this time she chooses to be mad. Her departure from reality puts her in these pathological interactions, in these games without end. This time instead of making others mad, she herself becomes mad in the hands of a bad character, which is the indispensable consequence of these deceifful interactions which are rooted in her departure from reality.

\section{References}

Bigsby, C. W. E. (1992). Modern American Drama 1945-1990. Cambridge: Cambridge University Press.

Clum, J. M. (2006). Williams: Masculinity and Homophobia. In B. Murphy (Ed.), Twentieth Century American Drama: Critical Concepts in Literary and Cultural Studies (pp. 271-290). New York: Routledge.

Cohn, R. (1977). The Garrulous Grotesques of Tennessee Williams. In S. S. Stanton (Ed.), Tennessee Williams: A Collection of Critical Essays (pp. 45-60). New Jersey: Englewood Cliffs.

Corrigan, M. A. (2006). Realism and Theatricalism in A Streetcar Named Desire. In B. Murphy (Ed.), Twentieth Century American Drama: Critical Concepts in Literary and Cultural Studies (pp. 214-225). New York: Routledge.

Heintzelman, G., \& Smith-Howard, A. (2005). Critical Companion to Tennessee Williams. New York: Facts on File, Inc.

Hirsch, F. (1979). A Portrait of the Artist: The Plays of Tennessee Williams. London: National University Publications.

Hovis, G. (2007). 'Fitty Percent Illusion' the Mask of the Southern Belle in Tennessee Williams's A Streetcar Named Desire, The Glass Menagerie, and 'Portrait of a Madonna'. In H. Bloom (Ed.), Bloom's Modern Critical Views: Tennessee Williams (pp. 171-185). New York: Bloom's Literary Criticism.

Jackson, E. M. (1966). The Broken World of Tennessee Williams. London: The University of Wisconsin Press.

Kataria, G. R. (2009). The Hetairas (Maggie, Myrtle, Blanche). In H. Bloom (Ed.), Bloom's Modern Critical Interpretations: Tennessee Williams's A Streetcar Named Desire (pp. 7-33). New York: Bloom's Literary Criticism.

Koprince, S. (2008). Neil Simon's Parodies of Tennessee Williams. In Ph. C. Kolin (Ed.), The Influence of Tennessee Williams: Essays on Fifteen American Playwrights (pp. 31-41). Jefferson: McFarland \& Company, Inc. Publishers.

Koprince, S. (2009). Domestic Violence in A Streetcar Named Desire. In H. Bloom (Ed.), Bloom's Modern Critical Interpretations: Tennessee Williams's A Streetcar Named Desire (pp. 49-60). New York: Bloom's Literary Criticism. 
Laing, R. D. (1960). The Divided Self: A Study of Sanity and Madness. London: Tavistock Publications.

Watzlawick, P., Bavelas, J. B., \& Jackson, D. D. (1967). Pragmatics of Human Communication: A Study of Interactional Patterns, Pathologies, and Paradoxes. New York: W. W. Norton and Company.

Williams, T. (1947). A Streetcar Named Desire. New York: New Directions. 